\title{
Large pituitary colloid cyst causing visual and hormonal defects
}

\author{
Richard Wei Chern Gan 지, ${ }^{1}$ Jemy Jose, ${ }^{1}$ Anuj Bahl'
}

Ear, Nose and Throat Department, Hull University Teaching Hospitals NHS Trust, Hull, UK

${ }^{2}$ Neurosurgical Department, Hull University Teaching Hospitals NHS Trust, Hull, UK

\section{Correspondence to} Richard Wei Chern Gan; richardwcgan@gmail.com

Accepted 11 June 2021

\section{DESCRIPTION}

An 80-year-old woman with a background of hypothyroidism, poor mobility and previous deep vein thrombosis of the lower limb presented to hospital following a fall and hypoglycaemia. Further investigations found her to have adrenal insufficiency and low or undetectable serum thyroid stimulating hormone and gonadotrophins. To investigate the cause of the low pituitary hormones, she underwent an MRI and CT scan of her pituitary with contrast (figures 1 and 2). This revealed a large predominantly cystic and a small solid component mass in the pituitary fossa with a suprasellar component compressing the optic chiasm. The hypointense area seen in the pituitary lesion on the T2-weighted MRI (figure 2) represents calcification that is seen in colloid cysts. However, the hypodensity of the lesion on CT is rare of colloid cysts (figure 2). Despite her reporting no visual problems, Goldmann visual fields detected a temporal visual field defect. To prevent further compression of the chiasm and deterioration of vision, the patient opted for surgical excision of the cyst. This was carried out via the endoscopic endonasal transphenoidal route. Intraoperative findings were that of a colloid cyst with its golden shining and gelatinous consistency (figure 3). On histology, the specimen was largely colloid material with some necrotic and inflammatory cells, consistent with the impression of a colloid cyst. ${ }^{1}$ There was no viable cyst wall in the specimen, with no epithelioid cells at multiple

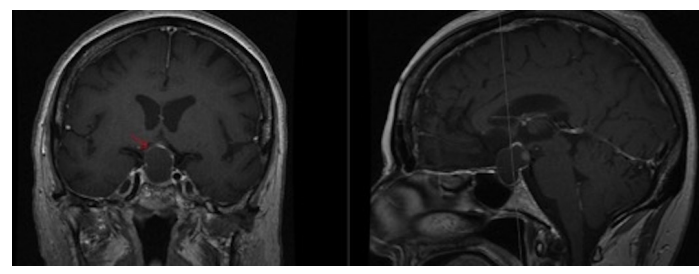

Figure 1 Preoperative T1-weighted MRI with gadolinium showing an elevated optic chiasm (arrow).

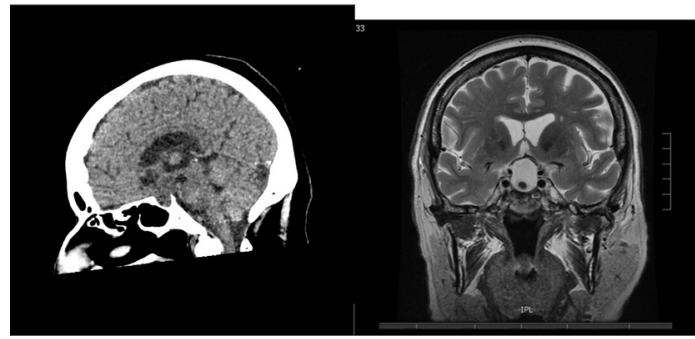

Figure 2 Preoperative CT (left) and T2-weighted MRI (right) images further characterising the pituitary lesion.

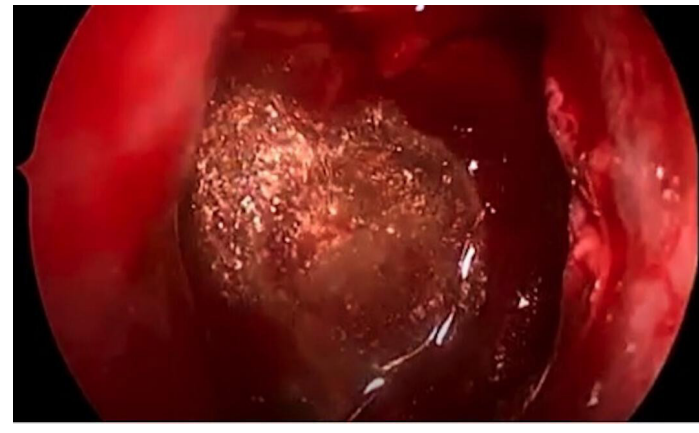

Figure 3 Endoscopic view of the gelatinous golden material extruding out of the pituitary fossa.

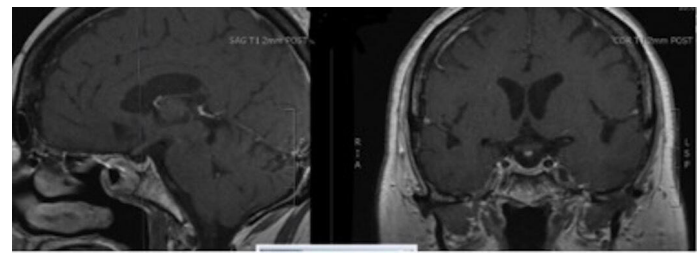

Figure 4 Postoperative MRI scan shows no residual disease, and the completely decompressed chiasm.

levels. Postoperative MRI showed complete excision of the cyst (figure 4). The patient's vision has

\section{Patient's perspective}

No headaches at all. Before the op, lots of headaches. Vision improved. Pain on one side of my face now gone.

\section{Learning points}

Pituitary lesions can be solid or cystic, and although very rare, a differential of such cystic pituitary lesions include a colloid cyst.

- They can cause compression on the optic chiasm and cause hypopituitarism by mass effect on the pituitary.

- It is important to test the visual fields in patients with pituitary lesions even though they report their vision as being normal, as there can be subtle temporal visual field defects picked up as an early sign. 
improved on Goldmann's field- testing. She will have surveillance MRI scanning to check for recurrence.

Contributors RWCG wrote up the case report and reviewed the literature on the subject. IJ and $A B$ were the operating surgeons and main clinicians in managing the case. They both reviewed the manuscript and provided editions and comments.

Funding The authors have not declared a specific grant for this research from any funding agency in the public, commercial or not-for-profit sectors.

Competing interests None declared.
Patient consent for publication Obtained.

Provenance and peer review Not commissioned; externally peer reviewed.

\section{ORCID iD}

Richard Wei Chern Gan http://orcid.org/0000-0002-9383-0374

\section{REFERENCE}

1 Bladowska J, Bednarek-Tupikowska G, Biel A, et al. Colloid cyst of the pituitary gland: case report and literature review. Pol J Radiol 2010;75:88.

Copyright 2021 BMJ Publishing Group. All rights reserved. For permission to reuse any of this content visit

https://www.bmj.com/company/products-services/rights-and-licensing/permissions/

BMJ Case Report Fellows may re-use this article for personal use and teaching without any further permission.

Become a Fellow of BMJ Case Reports today and you can:

Submit as many cases as you like

Enjoy fast sympathetic peer review and rapid publication of accepted articles

- Access all the published articles

Re-use any of the published material for personal use and teaching without further permission

Customer Service

If you have any further queries about your subscription, please contact our customer services team on +44 (0) 2071111105 or via email at support@bmj.com.

Visit casereports.bmj.com for more articles like this and to become a Fellow 